\title{
A CRITICAL ANALYSIS OF EMISSIONS AND ATMOSPHERIC DISPERSION OF POLLUTANTS FROM PLANTS FOR THE TREATMENT OF RESIDUAL MUNICIPAL SOLID WASTE
}

\author{
Gabriela IONESCU ${ }^{1}$, Dino ZARDI ${ }^{2}$, Werner TIRLER ${ }^{3}$, Elena Cristina RADA ${ }^{4}$, \\ Marco RAGAZZI ${ }^{5}$
}

\begin{abstract}
Această lucrare prezintă o analiză critică a diferitelor procese de gestionare a deşeurilor reziduale municipale solide, focalizându-se pe eliberarea poluanților în atmosferă. Regiunea Nord-Est a Italiei a fost aleasă ca studiu de caz. În acest context sunt analizate influența compoziției deşeurilor, precum şi implicațiile tehnologice disponibile. Sunt discutate procesele care determina dispersia poluanților în atmosferă şi riscurile pe care le ridică pentru sănătatea umana. Acest studiu oferă un set de criterii strategice care pot fi adoptate pentru minimizarea impactului asupra sănătații umane.
\end{abstract}

This paper provides a critical analysis of some processes determining a release of pollutants into the atmosphere, from residual municipal solid waste. The reference context is the situation in the North-East region of Italy. The role of waste composition and the implications of the available technologies are examined as well. Then the processes governing the dispersion into the atmosphere are discussed. Finally the different processes, by which emissions may determine an increased risk for human health, as well as criteria to be adopted in order to minimize this impact, are discussed.

Keywords: atmosphere; dispersion; emissions; human health; MSW; risk.

\footnotetext{
${ }^{1}$ Dr., Dept. of Energy Production and Use, POLITEHNICA University of Bucharest, Romania, email: gabriela_ionescu@ymail.com

${ }^{2}$ Prof., Dr., Dept. of Civil and Environmental Engineering, University of Trento, Trento, Italy, email: dino.zardi@ing.unitn.it

${ }^{3}$ Dr., Eco-Research Srl Bolzano, Italy, e-mail: w.tirler@eco-research.it

${ }^{4}$ PhD, Dr., Dept. of Civil and Environmental Engineering, University of Trento, Trento, Italy, email: elena.rada@ing.unitn.it

${ }^{5}$ Prof., Dr., Dept. of Civil and Environmental Engineering, University of Trento, Trento, Italy, email: marco.ragazzi@ing.unitn.it
} 


\section{Introduction}

The release of substances that affect air quality is to be included in the consequences of the increase of waste production, typical for our consumer society. A part of these substances is classified as air pollutants and thus noxious for the environment and human health [1]. Another part of them is classified as bad-smelling and so responsible of olfactory nuisance [2]. Last but not least, other substances are greenhouse gases, producing modifications in the radiation budgets controlling the earth surface temperature [3]. Assessing air pollution in complex morphologies becomes an important issue in order to implement mitigation measures and limit emissions [4]. Various research investigations conducted up to date have demonstrated that with respect to the self-ignition tendency i.e. tendency towards low temperature oxidation, solid waste represents a very complex and sensitive material [5]. The evolution of the regulations in the European Union, in the field of municipal solid waste (MSW) management, has improved the overall scenario but some aspects must be developed.

The aim of this study is to evaluate some critical aspects related to the role of MSW composition in air emission, the release of some air pollutants, the processes governing the dispersion of pollutants into the atmosphere and a case study of a RMSW incinerator.

\section{Role of MSW composition in air emission}

The composition of the incinerated feedstock stream has a direct influence on the Waste-to-Energy(WtE) technological conversion process and its environmental impact [2,6]. Primarily, in any waste thermal treatment, two aspects must be taken into account: the overall composition of MSW and the composition of the residual MSW (RMSW). Differences are related to the role of selective collection. The latter will influence the waste incineration as [7]:

- some materials should not be incinerated (they are more suitable for recycling, they are non-combustible or their by-products may be harmful);

- poor operating practices and the presence of chlorine in the MSW may lead to emissions containing highly toxic dioxins and furans (PCDD/F);

- the control of metal emissions may be difficult for inorganic wastes containing heavy metals.

This paper focuses on emissions from RMSW but takes into account also the trend in the composition of MSW in an European region where waste management is enhanced thanks to the adoption of the EU criteria: the North-East of Italy. In Table 1 some considerations on the trend in the MSW composition in the selected region are reported. 
Trend of MSW composition in the North-East of Italy

Table 1

\begin{tabular}{|c|c|}
\hline MSW Fraction & MSW composition trend \\
\hline Food waste & $\begin{array}{l}\text { The per-capita generation is nearly steady as the nutritional behaviour does } \\
\text { not changes, significantly among the population. Its percentage has decreased } \\
\text { in the last years as other MSW fractions increased (in particular, packaging } \\
\text { showed a significant increase in the last decades). The evolution of the } \\
\text { tourism sector in some areas can give an additional increase of food waste } \\
\text { generation. }\end{array}$ \\
\hline Garden waste & $\begin{array}{l}\text { In areas where domestic composting has been adopted, the amount of garden } \\
\text { waste collected has decreased slightly. This option has been favored through } \\
\text { the decrease of the tariff to be paid for domestic waste management. }\end{array}$ \\
\hline $\begin{array}{l}\text { Paper and } \\
\text { cardboard }\end{array}$ & $\begin{array}{l}\text { The recent economical crisis stopped the increase of cellulosic packaging that } \\
\text { characterised the recent decades. A few initiatives for reducing waste } \\
\text { generation are expected to slightly decrease its percentage in MSW. }\end{array}$ \\
\hline Plastics & $\begin{array}{l}\text { Also in this case the recent economical crisis stopped the increase of plastic } \\
\text { packaging. A few initiatives for reducing waste generation are expected to } \\
\text { slightly decrease its percentage in MSW. In particular, the substitution of } \\
\text { plastic shoppers with reusable bags is a strategy recently introduced on a large } \\
\text { scale. }\end{array}$ \\
\hline Glass & $\begin{array}{l}\text { Plastic bottles are more and more preferred to glass bottles because of their } \\
\text { weight. Glass percentage in MSW decreased in the last decades. }\end{array}$ \\
\hline Metals & In the last decades the use of Aluminium cans increased. \\
\hline $\begin{array}{l}\text { Exhausted } \\
\text { batteries }\end{array}$ & $\begin{array}{l}\text { An important limitation to the production of Hg batteries was introduced, with } \\
\text { consequences on its presence in MSW. The introduction of rechargeable } \\
\text { batteries is giving additional results in terms of content decrease. }\end{array}$ \\
\hline Composites & $\begin{array}{l}\text { Composite materials have been more and more introduced as packaging, with } \\
\text { some troubles for their recycling viability. }\end{array}$ \\
\hline Other fractions & The other fractions present are not relevant in terms of trend. \\
\hline
\end{tabular}

A part of these considerations can be applied also to other Italian regions and other European areas where the economic development is similar and the MSW management is close to be optimum according to the EU principles.

As a consequence of the explained characteristics, a general trend in Lower Heating Value (LHV) increase can be observed: its present value is around double compared to the one in the 70s.

In Table 2 the analysis concerns RMSW, obviously affected by the strategies of selective collection (SC). To this concern the SC in the North-East of Italy has reached very high values. In many municipalities the RMSW has been reduced to one third (or less) of the generated MSW. The present priority is to improve the quality of selection at the source. In particular the stream of light packaging is affected by significant mistakes of separation. 
Table 2

Trend of RMSW composition in the North-East of Italy

\begin{tabular}{|c|c|}
\hline RMSW & RMSW composition trend \\
\hline Food waste & $\begin{array}{l}\text { The percentage of food waste in the RMSW is quickly decreasing } \\
\text { because of the implementation of selective collection of the organic } \\
\text { fraction. In some areas the rate of collection at the source is expected } \\
\text { to reach } 80 \% \text { of this fraction. The selective collection of other fractions } \\
\text { partially counterbalances this phenomenon. The resulting percentage of } \\
\text { food waste can decrease to values around } 10 \% \text { in some extreme cases. } \\
\text { A consequence is the decrease of } \mathrm{Cl} \text { (from } \mathrm{NaCl} \text { ) in RMSW. }\end{array}$ \\
\hline Garden waste & $\begin{array}{l}\text { Where food waste selective collection is implemented also garden } \\
\text { waste is generally segregated, thus the considerations are similar to the } \\
\text { ones above ( } \mathrm{Cl} \text { excluded). }\end{array}$ \\
\hline Paper and cardboard & $\begin{array}{l}\text { The implementation of selective collection has decreased their } \\
\text { percentage in the RMSW. A } 100 \% \text { interception is not reachable as a } \\
\text { part of paper is not suitable for recycling because of the presence of } \\
\text { pollutants or undesired moisture. }\end{array}$ \\
\hline Plastics & $\begin{array}{l}\text { Only plastic packaging is selectively collected, thus the presence of } \\
\text { plastics in RMSW is still significant. This aspect contributes to a high } \\
\text { LHV of the RMSW, even higher than the limit of } 13 \mathrm{MJ} / \mathrm{kg} \text { set from } \\
\text { EU for classifying a waste non-suitable for landfilling. }\end{array}$ \\
\hline Glass & $\begin{array}{l}\text { Selective collection of glass has reached very high values thanks to the } \\
\text { citizen behaviour used to keep glass separated from other fractions for } \\
\text { safety reasons. }\end{array}$ \\
\hline Metals & Selective collection gives low \% of metals in RMSW. \\
\hline Exhausted batteries & $\begin{array}{l}\text { The decrease in Hg content has important consequences on } \mathrm{Hg} \\
\text { emissions in case of RMSW burning. }\end{array}$ \\
\hline Diapers & $\begin{array}{l}\text { The decrease of the RMSW amount (even down to } 35 \% \text { of the } \\
\text { generated MSW) can point out the presence of non-recyclable diapers } \\
\text { (in percentage). }\end{array}$ \\
\hline Composites & $\begin{array}{l}\text { Only in some areas a few composites can be recycled; thus their } \\
\text { presence in RMSW varies significantly. }\end{array}$ \\
\hline Other hazardous waste & $\begin{array}{l}\text { A good management of municipal hazardous waste, through source } \\
\text { separation, gives a lower presence of contaminants in the RMSW. } \\
\text { Expired medicaments remaining in the RMSW are close to zero. }\end{array}$ \\
\hline Other fractions & The other fractions present are not relevant in terms of trend. \\
\hline
\end{tabular}

Summing up, the described trend has a few consequences on the characteristics of RMSW: lower moisture; lower putrescibility; lower $\mathrm{Hg}$ and other persistent pollutants; lower Cl content; higher LHV. Concerning LHV, the increase of its value does not mean always an increase of energy available for a WtE plant, as selective collection diverts also fractions with a high energy content (such as plastics and paper). 


\section{Critical analysis of air pollutants release by RMSW management}

The atmospheric emission factors from RMSW treatment or disposal depend on: (a) presence of pollutants in the waste [8]; (b) prevention of pollutant generation [9]; (c) pollutant removal/ conversion after generation [10]. In order to develop a critical analysis of pollutants released into the atmosphere from RMSW options, the following steps were adopted:

- Step 1. Seeking of available options for RMSW treatment.

- Step 2. Selection of options suitable for real scale plants. After this selection the following options remained:

o biostabilization [11]

o bio-drying [12]

o anaerobic digestion [13]

o combustion [2]

o gasification [10]

o pyrolysis [10]

o landfilling [9]

These options must be seen as a part of an integrated system [14][15][16] but in this section the characteristics of each option are analyzed independently on the presence of other processes.

- Step 3. Seeking of literature data on emission factors to air from RMSW treatment (only for the above selected options), avoiding commercial data. Only data from ISI/Scopus articles were selected in order to have validated information.

- Step 4. Re-organization of data in three categories:

o non carcinogenic pollutants involving local impacts (these pollutants can be relevant both for hourly peaks and for yearly averages)

o carcinogenic pollutants involving local impacts (these pollutants are relevant only for long time human exposure as yearly averages)

o global warming pollutants (these pollutants, named greenhouse gases, are not strictly relevant locally as they involve global environmental processes)

- Step 5. Critical analysis of data previously selected in order to point out the trend of the RMSW sector. As a result, the Table 3 has been generated. 
Table 3

Main critical aspect related to emission factors (EFs) to air from RMSW processes

\begin{tabular}{|c|c|c|c|}
\hline & $\begin{array}{l}\text { Non-carcinogenic } \\
\text { pollutants (local) }\end{array}$ & $\begin{array}{l}\text { Carcinogenic pollutants of } \\
\text { local interest }\end{array}$ & $\begin{array}{l}\text { Global warming } \\
\text { pollutants }\end{array}$ \\
\hline $\begin{array}{l}\text { Biostabilization } \\
\text { (biological treatment } \\
\text { before landfilling) [17] }\end{array}$ & $\begin{array}{l}\text { Odour emissions can be } \\
\text { critical during the } \\
\text { maturation stage if the } \\
\text { accelerated fer_- } \\
\text { mentation is not } \\
\text { optimized. NOx from } \\
\text { Rigenerative Thermal } \\
\text { Oxidation (RTO) could } \\
\text { be relevant, if adopted, } \\
\text { because of methane } \\
\text { burning; EFs can be } \\
\text { even in the order of } \\
\text { hundreds } \\
\text { mg }_{\mathrm{NOx}} / \mathrm{kg}_{\text {waste. }}\end{array}$ & $\begin{array}{l}\text { PCDD/F already present } \\
\text { in RMSW could be } \\
\text { partially stripped and } \\
\text { released. This pheno_- } \\
\text { menon, recently pointed } \\
\text { out, is not yet taken into } \\
\text { account in all the EU } \\
\text { countries. PCDDF EFs } \\
\text { could be in the order of } \\
\text { tens of pg } \text { TEQ }^{2} \mathrm{~kg}_{\text {waste }} \text { The } \\
\text { variability depends on the } \\
\text { contamination of waste } \\
\text { and on the air treatment } \\
\text { line. }\end{array}$ & $\begin{array}{l}\mathrm{N}_{2} \mathrm{O} \text { can come from } \\
\text { biological processes; as } \\
\text { a consequence, in spite } \\
\text { of the biological } \\
\text { approach, greenhouse } \\
\text { gas emissions are not } \\
\text { zero (an additional } \\
\text { contribution comes } \\
\text { from electricity } \\
\text { consumption) }\end{array}$ \\
\hline $\begin{array}{l}\text { Biodrying (biological } \\
\text { pre-treatment for } \\
\text { energy options) } \\
\text { 19] }\end{array}$ & $\begin{array}{l}\mathrm{NO}_{\mathrm{x}} \text { from Rigene_- } \\
\text { rative Thermal Oxi_- } \\
\text { dation could be } \\
\text { relevant, if adopted. EFs } \\
\text { can be even in the order } \\
\text { of hundreds of } \\
\mathrm{mg}_{\mathrm{NOx}} / \mathrm{kg}_{\text {waste. }}\end{array}$ & $\begin{array}{l}\text { PCDD/F already present } \\
\text { in RMSW could be } \\
\text { partially stripped. Even if } \\
\text { lower than bio_- } \\
\text { stabilization, PCDDF EFs } \\
\text { could be in the order of } \\
\text { tens of } \text { pg }_{\mathrm{TEQ}} / \mathrm{kg}_{\text {waste }}\end{array}$ & $\begin{array}{l}\text { Similar to } \\
\text { biostabilization but with } \\
\text { lower emissions } \\
\text { (shorter process) }\end{array}$ \\
\hline $\begin{array}{ll}\text { Anaerobic } & \text { digestion } \\
\text { (biological } & \text { treatment } \\
\text { generating } & \text { methane) } \\
{[13,20]} & \end{array}$ & $\begin{array}{l}\mathrm{NO}_{\mathrm{x}} \text { emissions from } \\
\text { biogas combustion can } \\
\text { be not negligible. }\end{array}$ & $\begin{array}{l}\text { VOCs from biogas } \\
\text { burning should be } \\
\text { minimized; PCDD/F } \\
\text { could be also generated. } \\
\text { PCDDF EFs could be in } \\
\text { the order of tens of } \\
\mathrm{pg}_{\mathrm{TEQ}} / \mathrm{kg}_{\text {waste. }}\end{array}$ & $\begin{array}{l}\text { Not critical, if } \\
\text { compared to other } \\
\text { biological processes } \\
\left(\mathrm{CO}_{2} \text { is biogenic) }\right.\end{array}$ \\
\hline $\begin{array}{l}\text { Combustion } \\
\text { (thermochemical } \\
\text { oxidation) }[21,22,23]\end{array}$ & $\begin{array}{l}\mathrm{NO}_{\mathrm{x}} \mathrm{EFs} \text { could be } \\
\text { relevant if specific } \\
\text { removal stages are not } \\
\text { adopted. EFs can be } \\
\text { even in the order of } \\
\mathrm{g}_{\mathrm{NOx}} / \mathrm{kg}_{\text {waste in unopti_ }} \\
\text { mised plants, but }<300 \\
\mathrm{mg}_{\mathrm{NOx}} / \mathrm{kg}_{\text {waste }} \text { in the best } \\
\text { plants. }\end{array}$ & $\begin{array}{l}\text { PCDD/F and Cd are the } \\
\text { most relevant compounds. } \\
\text { PCDDF EFs could be in } \\
\text { the order of hundreds of } \\
\mathrm{Pg}_{\mathrm{TEQ}} / \mathrm{kg}_{\text {waste }} \text { if the plant } \\
\text { operates close to the } \\
\text { allowed limits. Some } \\
\text { plants can decrease EFs of } \\
\text { one order of magnitude. }\end{array}$ & $\begin{array}{l}\text { Non-biogenic } \mathrm{CO}_{2} \text { EFs } \\
\text { depend on RMSW }\end{array}$ \\
\hline \begin{tabular}{llr}
\multicolumn{2}{l}{ Gasification } & (process \\
aimed to & partial \\
oxidation) $[24]$ &
\end{tabular} & $\begin{array}{l}\text { CO emissions, after } \\
\text { syngas exploitation, can } \\
\text { be not negligible }\end{array}$ & $\begin{array}{l}\text { Heavy metals EFs could } \\
\text { be high if high } \\
\text { temperature is adopted }\end{array}$ & $\begin{array}{lr}\text { Non-biogenic } & \mathrm{CO}_{2} \\
\text { emissions depend } & \text { on } \\
\text { RMSW composition } & \end{array}$ \\
\hline $\begin{array}{l}\text { Pyrolysis (endothermal } \\
\text { process) [25] }\end{array}$ & $\begin{array}{l}\text { Char combustion can } \\
\text { generate high emissions } \\
\text { for many pollutants in } \\
\text { plants not optimized for } \\
\text { that }\end{array}$ & $\begin{array}{l}\text { Stripping of PCDD/F } \\
\text { already present in RMSW } \\
\text { could give unexpected } \\
\text { EFs (even in the order of } \\
\text { ng }_{\text {I-TEQ }} / \mathrm{kg}_{\text {waste }} \text { ) }\end{array}$ & $\begin{array}{l}\text { Net } \mathrm{CO}_{2} \text { EFs depend on } \\
\text { RMSW composition } \\
\text { and on the overall } \\
\text { strategy for the } \\
\text { pyrolysis outputs }\end{array}$ \\
\hline \begin{tabular}{l}
\multicolumn{3}{l}{ Landfilling (putrescible } \\
waste no longer \\
allowed) $[26,9]$
\end{tabular} & $\begin{array}{l}\text { Odour problems if not } \\
\text { correctly managed } \\
\text { (residual putrescibility) }\end{array}$ & $\begin{array}{l}\text { PCDD/F emissions from } \\
\text { bad quality biogas } \\
\text { burning in small landfills }\end{array}$ & $\begin{array}{l}\mathrm{CH}_{4} \text { fugitive emissions } \\
\text { if not correctly managed } \\
\text { (residual putrescib.) }\end{array}$ \\
\hline
\end{tabular}




\section{Processes governing the dispersion pollutants into the atmosphere}

The local interest is related to human exposure. Its level depends on the climatology of the area where a plant is located, on the amount of pollutants released into the atmosphere and on the way they are released [17,27]. The following sections of this paper deal with these concepts.

The fate of pollutants released into the atmosphere, through waste handling, treatment and storage processes, are determined by various combinations of weather and climate factors. Air contaminated with pollutants released into the atmosphere rises up to the level of neutral buoyancy. There, it is advected by the horizontal mean wind components, which usually exhibit an increasing speed at higher levels (the so called wind shear). Whole being advected, contaminants get mixed by smaller eddies generated by turbulence motions. The combined effect of advection by the mean flow and diffusion by continuous and chaotic turbulence movements determines the so called dispersion.

Turbulence can be generated either mechanically, i.e. by the interaction between the sheared wind and turbulent eddies, or thermally, i.e. through the buoyancy effect induced by the warming of cooling of the air close to the ground, mainly as a consequence of the surface heat budget following the diurnal cycle.

The physical processes explained above are mathematically described by the equation governing the local evolution in time $\mathrm{t}$ of the mean concentration $\bar{c}$ (i.e. averaged with respect to the turbulent fluctuations $c^{\prime}$ ). The rate of change of $\bar{c}$ (eq. (1)) is determined by three factors, i. e. respectively (a) the advection by the mean wind, represented as the scalar product of the wind velocity $\bar{u}$ by the gradient of the mean concentration, (b) the divergence of the turbulent flux

$\overline{u^{\prime} c^{\prime}}$ determined by the coupling between turbulent fluctuations of wind velocity and concentration, and (c) the sources (e.g. photochemical production) or sinks (e.g. removal by rain, snow or deposition on receptors) of air pollutants.

$$
\frac{\partial \bar{c}}{\partial t}=\underbrace{-\overline{\mathbf{u}} \cdot \nabla \bar{c}}_{\text {advection }} \underbrace{-\nabla \cdot \overline{\mathbf{u}^{\prime} c^{\prime}}}_{\text {turbulent diffusion }} \underbrace{+S}_{\text {production } / \text { removal }}
$$

It is clear that the wind structure is a key factor in determining the fate of pollutants. However this structure is determined by the scale at which air motions are generated. Usually atmospheric motions are hierarchically categorised into four main scales. The largest one is known as planetary scale, as it includes motions occurring on an extent embracing all or most of the planet, as part of the so called general circulation of the atmosphere). A smaller scale is determined by typical features of the pressure and temperature field, such as high and low pressure structures (anticyclones and cyclones respectively) often associated with moving fronts, i.e. regions of sharp temperature contrasts between adjacent air 
masses displaying different mean temperatures. This scale is a synoptic scale. A typical horizontal length for this scale is of order of some thousands kilometres. The so called mesoscale includes phenomena occurring in a range of some tenths to some hundreds kilometres. It includes phenomena determined by geography (mountains, deserts, sea and lake shore). Typical phenomena falling in these categories are sea breezed and diurnal mountain and valley winds detailed in Fig. 1 and 2. Then there is the broad range of local scale phenomena, including urban effects, roughness-induced phenomena, turbulent motions.

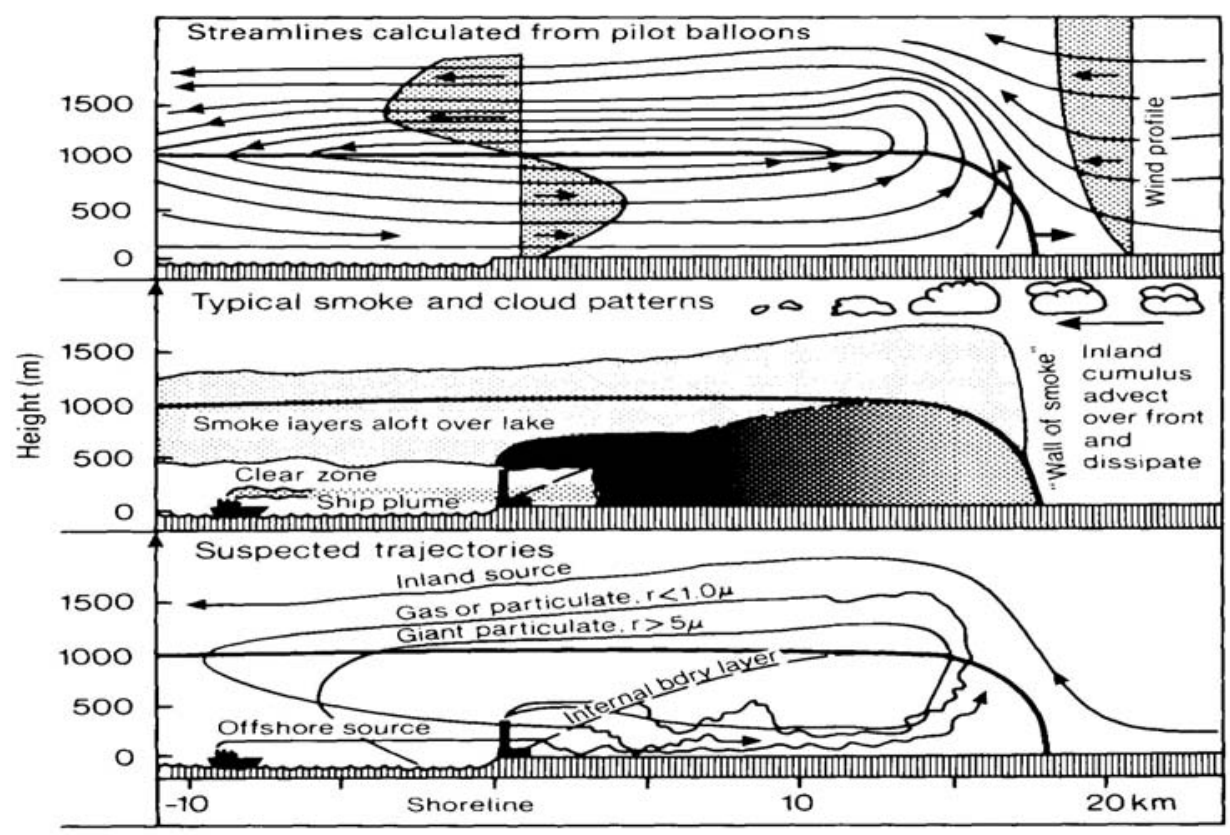

Fig. 1. The form of the lake Breez front near Chicago measured using tetroons and aircraft. Special features are the "wall of smoke” and the evidence for recirculation [28]

In the presented case study, the Italian territory is covered by a $23.2 \%$ of plain areas, $41.5 \%$ by hills and $35.2 \%$ by mountains. About half of the population lives in plain regions (49.7\%), but the remaining half live hills in $(37.3 \%)$ or mountains 13\%). Furthermore, it is bounded by $8490 \mathrm{~km}$ of maritime coasts. The local climatology can strongly affect the dilution of pollutants emitted from a plant treating RMSW. The selection of a site for a new plant can play an important role: from site to site the local impact can vary of one order of magnitude. 


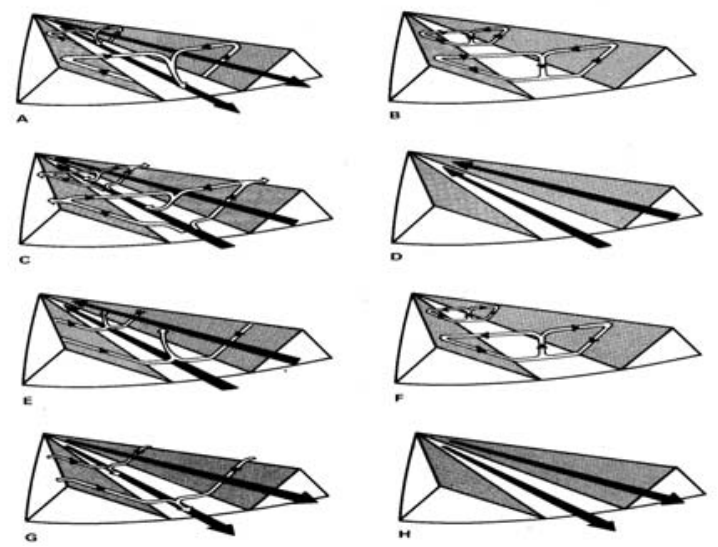

Fig. 2. Diurnal cycle of valley winds: (a) Sunrise: onset of upslope winds (white arrows); continuation of mountain wind (black arrows). Valley is cold, plains are warm. (b) Forenoon (about 0900): strong slope winds, transition from mountain wind to valley wind. Valley temperature is same as plain. (c) Noon and early afternoon: diminishing slope winds; fully developed valley wind. Valley is warmer than plains. (d) Late afternoon: slope winds have ceased, valley wind continues. Valley is still warmer than plain. (e) Evening: onset of down-slope winds, diminishing valley wind. Valley is slightly warmer than plains. (f ) Early night: well developed down-slope winds, transition from valley wind to mountain wind. Valley and plains are at the same temperature. (g) Middle of the night: down-slope winds continue, mountain wind fully developed. Valley is colder than plains. (h) Late night to morning: down-slope winds have ceased, mountain wind fills valley. Valley is colder than plain [28].

\section{Case study}

A typical case useful for understanding the local impact of the emissions from a RMSW treatment plants is the one concerning an incinerator. This impact depends on many factors: site characteristics (in particular climatology); amount of RMSW to be treated; LHV of the RMSW; emission concentrations at the stack during operating conditions; stack height; off-gas velocity at the stack; off-gas temperature at the stack; yearly operating hours.

Thanks to the optimization of all these parameters, a modern incinerator can have a negligible impact on the interested area. An example of that can come from the case of the incinerator of Bolzano. In this paper, a zoom on the role of the most relevant carcinogenic pollutants is presented. In Fig. 3 some results of the modelling of pollutant dispersion and deposition are presented. The present results come from an integrated approach developed at the Civil and Environmental Department of the University of Trento.

These results suggest that the process of transport and dispersion of pollutants from the operation of the incineration plant crucially depends on the diurnal cycle of the valley winds. In the case of Northerly wind, the process is 
dominated by the flow channel along the Adige valley where the maximum concentration values at ground level occur south of the incinerator at a distance of about $3 \mathrm{~km}$. The scenario becomes more complicated in the case of wind flow from the southern sector: as stated, the main flow is directed, depending on the atmosphere conditions that exist in the valley town, towards the valley of Isarco or to Merano. The average year shows that this phenomenon gives rise to two areas of maximum concentration that take place near the town of Bolzano, the first North-West part of the town and the second located approximately in the centre of the town.

In particular, Fig. 3 concerns the contribution of $\mathrm{Cd}$ emissions to the air concentration at ground level. For this parameter, the deposition [29] is less relevant as its impact is most significant in case of inhalation. The highest contribution is only about $1.1 \cdot 10^{-4} \mathrm{ng} / \mathrm{m}^{3}$ whilst in EU its limit in air is $5 \mathrm{ng} / \mathrm{m}^{3}$.

Concerning the contribution of PCDD/F to the concentration in air at ground level, the highest values are in urbanized areas but its contribution is so low that this impact has been considered acceptable: the peak value resulted only $0.04 \mathrm{fg} g_{\mathrm{TEQ}} / \mathrm{m}^{3}$. A verification of this amount was made measuring the PCDD/F air and soil concentrations in the area affected by the plant. The measured value in air resulted $67 \mathrm{fg} \mathrm{TEQ}_{\mathrm{TE}} / \mathrm{m}^{3}$ demonstrating that a modern incinerator can give a negligible contribution to the presence of PCDD/F in an area.

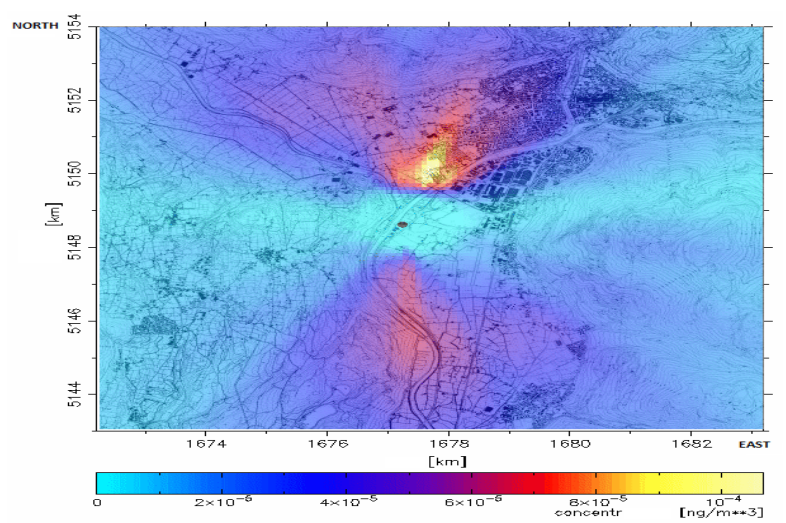

Fig. 3. Contribution to the Cd average yearly concentration in air at ground level

Moreover, additional directional (wind dependent) samplings in the following years confirmed that PCDD/F in air is not critical in the Bolzano area and there is not a significant influence from the incinerator.

A confirmation of the low impact was made also characterizing the soil in the area; the obtained value was $1.23 \mathrm{ng}$ TEQ $/ \mathrm{kg}$, lower than the limit for residential areas $\left(10 \mathrm{ng}_{\mathrm{TEQ}} / \mathrm{kg}\right)$. Additional samplings in the urban area confirmed that the typical values are generally lower than $2 \mathrm{ng}_{\mathrm{TEQ}} / \mathrm{kg}$. 
Taking into account only the contribution of PCDD/F to the air concentration, an underestimation of the impact of these pollutants can emerge. Indeed an important aspect concerns the deposition of PCDD/F and their role depending on the local food production and consumption. In the case study the deposition results gave a peak value as $13 \mathrm{pg}_{\mathrm{TEQ}} \mathrm{m}^{-2} \mathrm{y}^{-1}$. A guideline value come from Flanders [30], with a value of $1,241 \mathrm{pg} \mathrm{m}^{-2} \mathrm{y}^{-1}$ demonstrating the low impact of the plant.

As a carcinogenic pollutant has never a health risk equal to zero, it is important to assess the incremental risk related to a cancer event referred to the most exposed person in the area and the overall risk. The results of the adoption of a health risk method demonstrated that the individual one is $<<10^{-6}$ and the overall one is $<<1$.

The positive results of the above impact analysis allowed the local administration to propose a new RMSW combustion plant in the same site in order to substitute the existing one, as approaching its end of life. As pointed out in Table 3, the NOx emission minimization was assumed as a priority for the new plant. The incinerator under construction will guarantee average daily NOx concentration at the stack lower than $40 \mathrm{mg} / \mathrm{Nm}^{3}$, significantly lower than the limit requested at national level.

These positive results are related to an optimized plant. In the sector of waste management sub-optimum design solutions can give not negligible local impact also when incineration is not adapted [6]. Both for bio-mechanical plants and for landfilling, the release of pollutants at ground level can suffer from a bad dilution that does not protect the residential areas in the surroundings. A demonstration of the not optimized way of release from a biofilter comes from the TOC parameter: the German regulation on bio-mechanical plants [6] sets a TOC emission factor value as a limit to be complied with. For the TOC parameter it is asked to emit less than $55 \mathrm{mg} / \mathrm{kg}_{\text {RMSw. }}$. If we take into account that an incinerator could be authorised to have at the stack $5 \mathrm{mg} / \mathrm{Nm}^{3}$, in the case of a specific air flow-rate of $6 \mathrm{Nm}^{3} / \mathrm{kg}_{\mathrm{RMSw}}$ we could have an emission factor to air of 5 x $6=30$ $\mathrm{mg} / \mathrm{kg}_{\mathrm{MSw}}$, lower than the one for bio-mechanical plants $\left(30<55 \mathrm{mg} / \mathrm{kg} \mathrm{RMSW}_{\text {). It }}\right.$ is clear that, with similar emission factors but different height of release, the local impact of the incinerator will be significantly lower, for this parameter.

From these considerations, a modification of the regulations concerning low level emissions from MSW treatment plants is compulsory. To this concern, it must be pointed out that a significant number of composting plant have been recently stopped in Italy because of the unoptimized release of process air. In this case the odour parameter gives a direct idea of the bad managed impact of the plant. 


\section{Conclusions}

The contents of this paper demonstrate that trends of the environmental impact in the MSW sector can be found thanks to the evolution of the waste management strategies. However some prevention activities in terms of emissions to the atmosphere cannot decrease the importance of the analysis of the local meteorology in order to verify the compatibility of a site with the proposal of a plant. A problem to be faced with can be the lack of meteorological data if the region of the site has not an adequate tradition of meteorological data collection. In this case a specific campaign of at least one year should be planned. Moreover, in the MSW sector there is a unbalanced approach from the regulatory point of view, as the role of low level emissions is not managed with the same attention of the case of emissions from a high stack. In this last case, dispersion and deposition modelling demonstrate that modern incinerators may be constructed keeping very low their local impact. This result cannot be generalized as the role of meteorology can significantly change the local incidence of a plant in terms of air pollution. Additionally the concept of "modern" must be related to low emission values really guaranteed at the stack.

\section{R E F E R E N C E S}

[1]. D.M. Cocarta, E.C. Rada, M. Ragazzi, A. Badea and T. Apostol, “A contribution for a correct vision of health impact from municipal solid waste treatments”, Environ. Technol., vol. 30, no. 9, 2009, pp. 963-968.

[2]. E.C. Rada, I.A. Istrate and M. Ragazzi, "Trends in the management of residual municipal solid waste”, Environ. Technol., vol. 30, no. 7, 2009, pp. 651-661.

[3]. M. Ragazzi, E.C. Rada and D. Antolini, "Material and energy recovery in integrated waste management systems: An innovative approach for the characterization of the gaseous emissions from residual MSW bio-drying”, Waste Manage. vol. 31, no. 9-10, 2011, pp. 2085-2091.

[4]. S. Ciuta, M. Schiavon, A. Chistè, M. Ragazzi, E.C. Rada, M. Tubino, A. Badea and T. Apostol, "Role of feedstock transport in the balance of primary PM emissions in two case-studies: RMSW incineration vs. Sintering plant”, U.P.B. Sci. Bull., serie D, vol. 74, no. 1, 2012, pp. 211-218.

[5]. A. Jovovic, G. Vujic, M. Pavlovic, D. Radic, D. Jevtic and M. Stanojevic, "Spontaneous Ignition/Low Temperature Oxidation of Municipal Solid Waste”, Rev. Chim. (Bucharest), vol. 62, 2011, pp.108-112

[6]. E.C. Rada, M. Ragazzi, V. Panaitescu and T. Apostol, "Some research perspectives on emissions from bio-mechanical treatments of municipal solid waste in Europe”, Environ. Technol., vol. 26, no. 11, 2005, pp. 1297-1302

[7]. G. McKay, “ Dioxin characterisation,formation and minimisation during municipal solid waste (MSW) incineration: review”, Chem Eng J., vol. 86, 2002, pp. 343-368.

[8] E.C. Rada, A. Franzinelli, M. Ragazzi, V. Panaitescu, T. Apostol, "Modelling of PCDD/F release from MSW bio-drying”, Chemosphere, vol. 68, no. 9, 2007, pp. 1669-1674. 
[9]. D.P. Komilis, R.K. Ham, R.K. and R. Stegmann, "The effect of municipal solid waste pretreatment on landfill behavior: a literature review”, Waste Manage Res., vol. 17, no. 1, 1999, pp 10-19.

[10] M. Ragazzi, E.C. Rada, "Multi-step approach for comparing the local air pollution contributions of conventional and innovative MSW thermo-chemical treatments", Chemosphere, vol. 89, no.6, 2012, pp. 694-701

[11] E.C. Rada, M. Ragazzi,V. Panaitescu,T. Apostol," The role of bio-mechanical treatments of waste in the dioxin emission inventories, Chemosphere, vol. 62, no. 3, 2006, pp. 404-410

[12] E.C. Rada, M. Ragazzi, A. Badea, "MSW Bio-drying: Design criteria from A 10 years research“, U.P.B. Sci. Bull., serie D, vol. 74 , no. 3, 2012, pp. 209-216

[13]. E.C. Rada and M. Ragazzi, "Critical analysis of PCDD/F emissions from anaerobic digestion”, Water Sci Technol., vol. 58, no. 9, 2008, pp. 1721-1725.

[14] E.C. Rada, M. Venturi, M. Ragazzi, T. Apostol, C. Stan, C, Marculescu, “ Bio-drying role in changeable scenarios of Romanian MSW management”, Waste and Biomass Valor., vol. 1, no. 2, 2010, pp. 271-279.

[15] E.C. Rada, I.A. Istrate,V. Panaitescu, M. Ragazzi, T.M. Cirlioru, T. Apostol, "A comparison between different scenarios of Romanian municipal solid waste treatment before landfilling”, Environ. Eng. Manage. J., vol. 9, n. 4, 2010, pp. 589-596.

[16] E.C. Rada, M. Ragazzi, V. Panaitescu, "MSW bio-drying: An alternative way for energy recovery optimization and landfilling minimization”, U.P.B. Sci Bull., serie D., vol. 71, no. 4, 2009 , pp. 113-120.

[17]. Q. Liu, M. Li, R. Chen, Z.Y. Li, G.R. Qian, T.C. An, J.M. Fu and G.Y. Sheng, "Biofiltration treatment of odors from municipal solid waste treatment plants “,Waste Manage., vol. 29, no. 7, 2009, pp. 2051-2058

[18]. E.C. Rada, M. Ragazzi, D. Zardi, L. Laiti and A. Ferrari, “ PCDD/F enviromental impact from municipal solid waste bio-drying plant”, Chemosphere, vol. 84, no. 3, 2011, pp. 289295.

[19]. C.A. Velis, P.J. Longhurst, G.H. Drew, R. Smith and S.J.T. Pollard, "Biodrying for mechanical-biological treatment of wastes: A review of process science and engineering “, Bioresour. Technol., vol. 100, no. 11, 2009, pp. 2747-2761.

[20]. M.A. Latif, A. Ahmad, R. Ghufran and Z.A. Wahid, "Effect of temperature and organic loading rate on upflow anaerobic sludge blanket reactor and $\mathrm{CH}_{4}$ production by treating liquidized food waste”, Environ. Progr. Sustain. Energy, vol. 31, no. 1, 2012, pp. 114-121.

[21]. S. Consonni and F. Vigano, "Waste gasification vs. conventional Waste-To-Energy: A comparative evaluation of two commercial technologies”, Waste Manage., vol 32, no. 4, 2012, pp. 653-666.

[22]. C. Marculescu, G. Antonini and A. Badea, "Analysis on the MSW thermal degradation processes”, Global Nest J., vol 9, 2007, pp. 57-62.

[23]. M.J. Quina, J.C. Bordado and R.M. Quinta-Ferreira, "Treatment and use of air pollution control residues from MSW incineration: An overview”, Waste Manage., vol. 28, 2008, pp. 2097-2121.

[24]. U. Arena, "Process and technological aspects of municipal solid waste gasification. A review”, Waste Manage., vol. 32, no. 4, 2012, pp. 625-639.

[25]. P. Baggio, M. Baratieri, A. Gasparella and G.A. Longo, "Energy and environmental analysis of an innovative system based on municipal solid waste (MSW) pyrolysis and combined cycle”, Appl. Therm. Eng., vol. 28, no. 2-3, 2008, pp. 136-144.

[26]. D.B. Yue, J.G. Liu, P. Lu, Y. Wang, J. Liu and Y.F., "Release of non-methane organic compounds during simulated landfilling of aerobically pretreated municipal solid waste”, $\mathrm{J}$ Environ Manage., vol. 101, 2012, pp. 54-58. 
[27]. L. Giovannini, D. Zardi and M. Franceschi, "Analysis of the Urban Thermal Fingerprint of the City of Trento in the Alps”, J. Appl. Meteorol Climatology, vol. 50, no. 5, 2011, pp. 1145-1162.

[28]. J.E. Simpson, "Sea breeze and local winds”, Water Sci Technol., vol. 58, 2008, pp. 17211725.

[29]. A. Lucaciu, C. Motoc, M. Jelea and S.G. Jelea,. "Survey of heavy metal deposition in Romania: Transylvanian plateau and western carpathians mountains”, U.P.B. Sci. Bull., vol. 72, no. 2, 2010, pp. 171-178.

[30]. L. Van Lieshout, M. Desmedt, E. Roekens, R. De Fré, R. Van Cleuvenbergen and M. Wevers, "Deposition of dioxins in Flanders (Belgium) and a proposition for guide values", Atmos. Environ., vol. 35, 2001, pp. 83-90. 